\title{
PREVALENCE OF LOW VISION AMONG SCHOOL CHILDREN IN A RURAL BLOCK OF HARYANA
}

Seema Sharma ${ }^{1}$, B. M. Vashisht², Satinder Vashisht ${ }^{3}$, Seema Chaudhary 4 , Neelu Saluja ${ }^{5}$, Suresh Kumar6, S. M. Pandey ${ }^{7}$

${ }^{1}$ Associate Professor, Department of Community Medicine, MAMC, Agroha.

2Professor, Department of Community Medicine, PGIMS, Rohtak.

${ }^{3}$ Senior Medical Officer, Regional Institute of Ophthalmology, PGIMS, Rohtak.

${ }^{4}$ Professor, Department of Community Medicine, MMAC, Agroha.

${ }_{5}^{5}$ Associate Professor, Department of Community Medicine, MAMC, Agroha.

${ }^{6}$ Medical Officer, Haryana Civil Medical Services, India.

${ }^{7}$ Assistant Professor (Statistics), Department of Community Medicine, MAMC, Agroha.

ABSTRACT
BACKGROUND
Low vision and blindness in children are important because of their impact on the child's development, education, future work
opportunities and quality of life. These negative effects are experienced throughout the child's life. It leads to serious social and
economic burden to the family and the society.
The objective of this study is to assess the visual acuity and prevalence of visual impairment among the students in a rural
block of Haryana.

\section{MATERIALS AND METHODS}

This cross-sectional study was done in Govt. Senior Secondary Schools of Block Lakhanmajra, Haryana. Out of 16 Govt. Senior Secondary Schools, 4 were randomly chosen. Students aged 6 - 15 years studying in class 1 to 10 were included in the study. The age of students was ascertained as per the school records. Visual Acuity (VA) test was performed using Snellen's E chart. Assessment of VA of all the students was done at 6 meters in a well-illuminated room. The findings of clinical examination were recorded on a pre-tested proforma. After collection, the whole data was compiled, analysed and appropriate statistical tests like simple proportions and chi-square $\left(\boldsymbol{N}^{2}\right)$ test were applied.

\section{RESULTS}

The prevalence of VA $\leq 6 / 9$ either in better eye or worse eye was more in girls as compared to boys. Low vision according to WHO criteria (VA $\leq 6 / 18$ in better eye) was found to be more prevalent in girls (3.4\%) as compared to boys (1.7\%). Out of total 34 students (2.6\%) were having low vision according to WHO criteria. The prevalence VA $\leq 6 / 9$ either in better eye or worse eye was more in higher age groups as compared to lower age groups. VA $\leq 6 / 18$ was not found before the age of 10 years. The association of visual acuity with increase in age group was found to be highly significant.

\section{CONCLUSION}

Vision screening of school children in developing countries could be useful in detecting curable causes of vision problems provided detected at the early stage, especially refractive errors by which long-term visual disability could be avoided.

\section{KEYWORDS}

Visual Acuity, Impaired Vision, Low Vision, Rural Area, School Children.

HOW TO CITE THIS ARTICLE: Sharma S, Vashisht BM, Vashisht S, et al. Prevalence of low vision among school children in a rural block of Haryana. J. Evolution Med. Dent. Sci. 2017;6(67):4802-4804, DOI: 10.14260/Jemds/2017/1041

\section{BACKGROUND}

Visual acuity is the sharpness of vision measured as the maximum distance at which a person can see certain objects, divided by the maximum distance at which a person with normal eyesight can see the same object. Visual acuity (VA) commonly refers to the clarity of vision. Visual acuity is dependent on optical and neural factors.

Around 39 million people are blind and 246 million have low vision. An estimated 19 million children below age 15

Financial or Other, Competing Interest: None.

Submission 12-07-2017, Peer Review 09-08-2017,

Acceptance 16-08-2017, Published 21-08-2017.

Corresponding Author:

Seema Sharma,

Associate Professor

Department of Community Medicine,

Maharaja Agrasen Medical College, Agroha,

Hisar-125047, Haryana, India.

E-mail: ss4_gunu@yahoo.co.in

DOI: $10.14260 /$ jemds $/ 2017 / 1041$ years are visually impaired. Of these 12 million children are visually impaired due to refractive errors, a condition that could be easily diagnosed and corrected; 1.4 million are irreversibly blind for the rest of their lives and need visual rehabilitation interventions for a full psychological and personal development. ${ }^{1}$

Vision is the most important special sense in human beings. Normal vision is essential for normal physical, mental, psychological development and education. Considering the fact that $30 \%$ of India's blind lose their eyesight before the age of 20 years and many of them are under five when they become blind, the importance of early detection and treatment of ocular disease and vision impairment among young children is obvious. ${ }^{2}$

Visual impairment is a worldwide problem that has a significant socioeconomic impact. Childhood blindness is a priority area because of the number of years of blindness that ensues. Data on the prevalence and causes of blindness and severe visual impairment in children are needed for planning and evaluating preventive and curative services including planning special education and low vision services. ${ }^{3}$ 
Child's vision is essential for successful learning in school. When the vision suffers, pupil's routine school work and dayto-day activities also get affected. The students are not mature enough to point out the deficiency at the early stage or the parents have no idea on the gradually developing vision problem. This results in tiredness, distraction, headache and a few other disorders. Children who have been affected could not concentrate on studies or on any other curricular, extracurricular or recreational activities. ${ }^{4}$

Sometimes $20 / 20$ vision is used in place of $6 / 6$ vision; $20 / 20$ vision is a term used to express normal visual acuity measured at a distance of 20 feet. If you have 20/20 vision, you can see clearly at 20 feet what should normally be seen at that distance. If you have $20 / 100$ vision, it means that you must be as close as 20 feet to see what a person with normal vision can see at 100 feet. $^{5}$

According to WHO (ICD-10), visual impairment is the consequence of a functional loss of vision rather than an eye disorder itself, which is defined as vision of equal to or better than $6 / 18$ in the better eye. ${ }^{6}$

\section{Objective}

The main intention of this study is to assess the visual acuity and visual impairment among the students in a rural block of Haryana.

\section{MATERIALS AND METHODS}

The present cross-sectional study was carried out in block Lakhanmajra, which is the field practice area attached to the Department of Community Medicine, Pt. B. D. Sharma Postgraduate Institute of Medical Sciences, Rohtak. The study subjects were school going children in the age group of $6-15$ years. Out of total 16 Govt. schools existing in the block, two girls' schools and two boys' schools were randomly selected and all the students between 6 - 15 years of age, studying in class $1^{\text {st }}$ to $10^{\text {th }}$ were included in the study. The students were divided into three age groups: 6 - 10 years, 10 - 13 years and 13 - 15 years. All concerned Principals, teachers and students were briefed about the study. The students present on day of visit were included in the study. No followup visits were done. The age of students was ascertained as per the school records. Visual Acuity (VA) test was performed using Snellen's E chart. Assessment of VA of all the students was done at 6 metres in a well-illuminated room.

If distant visual acuity was $<6 / 6$, then those students were subjected to refraction by ophthalmic assistant. VA
$<6 / 6$ was taken as criteria of defective vision, because criterion of low vision according to WHO (VA $\leq 6 / 18$ in better eye) is already grossly subnormal for school children.

Information was collected on a pretested semi-structured schedule. After collection, the whole data was compiled, analysed and appropriate statistical tests like simple proportions and chi-square $\left(\boldsymbol{N}^{2}\right)$ test were applied.

\section{RESULTS}

The prevalence of VA $\leq 6 / 9$ either in better eye or worse eye was more in girls as compared to boys. Low vision according to WHO criteria (VA $\leq 6 / 18$ in better eye) was found to be more prevalent in girls $(3.4 \%)$ as compared to boys $(1.7 \%)$. Out of total 34 students (2.6\%) were having low vision according to WHO criteria. The association of visual acuity with sex was found to be strongly significant in both better eye as well as worse eye (Table I).

The prevalence $\mathrm{VA} \leq 6 / 9$ either in better eye or worse eye was more in higher age groups as compared to lower age groups. VA $\leq 6 / 18$ was not found before the age of 10 years. Both the tables show that the no. of cases were much more after the age of $10 \mathrm{yrs}$. The association of visual acuity with increase in age group was found to be highly significant (Table II).

\begin{tabular}{|c|c|c|c|c|c|c|}
\hline \multirow[b]{3}{*}{$\begin{array}{l}\text { Visual } \\
\text { Acuity }\end{array}$} & \multicolumn{3}{|c|}{ Better Eye } & \multicolumn{3}{|c|}{ Worse Eye } \\
\hline & \multicolumn{2}{|c|}{ Sex } & \multirow{2}{*}{$\begin{array}{c}\text { Total } \\
{[\%]}\end{array}$} & \multicolumn{2}{|c|}{ Sex } & \multirow{2}{*}{$\begin{array}{c}\text { Total } \\
{[\%]}\end{array}$} \\
\hline & $\begin{array}{c}\text { Boys } \\
{[\%]}\end{array}$ & $\begin{array}{c}\text { Girls } \\
{[\%]}\end{array}$ & & $\begin{array}{c}\text { Boys } \\
\text { [\%] }\end{array}$ & $\begin{array}{c}\text { Girls } \\
{[\%]}\end{array}$ & \\
\hline $6 / 6$ & $\begin{array}{c}474 \\
{[92.9]}\end{array}$ & $\begin{array}{c}643 \\
{[85.2]}\end{array}$ & $\begin{array}{c}1117 \\
{[88.3]}\end{array}$ & $\begin{array}{c}464 \\
{[90.9]}\end{array}$ & $\begin{array}{c}629 \\
{[83.3]}\end{array}$ & $\begin{array}{c}1093 \\
{[86.4]}\end{array}$ \\
\hline $\begin{array}{l}6 / 9- \\
6 / 12\end{array}$ & $\begin{array}{c}30 \\
{[5.9]}\end{array}$ & $\begin{array}{c}84 \\
{[11.1]}\end{array}$ & $\begin{array}{c}114 \\
{[9.1]}\end{array}$ & $\begin{array}{c}31 \\
{[6.1]}\end{array}$ & $\begin{array}{c}86 \\
{[11.4]}\end{array}$ & $\begin{array}{c}117 \\
{[9.3]}\end{array}$ \\
\hline $\begin{array}{l}6 / 18- \\
6 / 60\end{array}$ & $\begin{array}{c}6 \\
{[1.2]}\end{array}$ & $\begin{array}{c}28 \\
{[3.7]}\end{array}$ & $\begin{array}{c}34 \\
{[2.6]}\end{array}$ & $\begin{array}{c}15 \\
{[3.0]}\end{array}$ & $\begin{array}{c}40 \\
{[5.3]}\end{array}$ & $\begin{array}{c}55 \\
{[4.4]}\end{array}$ \\
\hline Total & $\begin{array}{c}510 \\
{[100]}\end{array}$ & $\begin{array}{c}755 \\
{[100]}\end{array}$ & $\begin{array}{l}1265 \\
{[100]}\end{array}$ & $\begin{array}{c}510 \\
{[100]}\end{array}$ & $\begin{array}{c}755 \\
{[100]}\end{array}$ & $\begin{array}{l}1265 \\
{[100]}\end{array}$ \\
\hline $\begin{array}{c}\chi^{2} \\
\text { Value } \\
\text { (df-2) }\end{array}$ & \multicolumn{3}{|c|}{27.735} & \multicolumn{3}{|c|}{17.702} \\
\hline $\begin{array}{c}\mathrm{P} \\
\text { Value }\end{array}$ & \multicolumn{3}{|c|}{$0.000^{*}$} & \multicolumn{3}{|c|}{$0.000^{*}$} \\
\hline
\end{tabular}

\begin{tabular}{|c|c|c|c|c|c|c|c|c|}
\hline \multirow{3}{*}{$\begin{array}{l}\text { Visual } \\
\text { Acuity }\end{array}$} & \multicolumn{4}{|c|}{ Better Eye } & \multicolumn{4}{|c|}{ Worse Eye } \\
\hline & \multicolumn{3}{|c|}{ Age Groups (Years) } & \multirow[b]{2}{*}{$\begin{array}{c}\text { Total } \\
\mathrm{n}=1265 \\
{[\%]}\end{array}$} & \multicolumn{3}{|c|}{ Age Groups (Years) } & \multirow[b]{2}{*}{$\begin{array}{c}\text { Total } \\
\mathrm{n}=1265 \\
{[\%]}\end{array}$} \\
\hline & $\begin{array}{c}(6-10) \\
\mathrm{n}=282 \\
{[\%]}\end{array}$ & $\begin{array}{c}(10-13) \\
\mathrm{n}=536 \\
{[\%]}\end{array}$ & $\begin{array}{c}(13-15) \\
\mathrm{n}=447 \\
{[\%]}\end{array}$ & & $\begin{array}{c}\mathrm{n}=282 \\
{[\%]}\end{array}$ & $\begin{array}{c}(10-13) \\
\mathrm{n}=536 \\
{[\%]}\end{array}$ & $\begin{array}{c}(13-15) \\
\mathrm{n}=447 \\
{[\%]}\end{array}$ & \\
\hline $6 / 6$ & 270 [95.7] & $463[86.4]$ & $384[85.9]$ & $\begin{array}{c}1117 \\
{[88.3]}\end{array}$ & 269 [95.4] & $459[85.6]$ & 365 [81.7] & $\begin{array}{c}1093 \\
{[86.4]}\end{array}$ \\
\hline $6 / 9-6 / 12$ & $\begin{array}{c}12 \\
{[4.3]}\end{array}$ & $\begin{array}{c}53 \\
{[10.0]}\end{array}$ & $\begin{array}{c}49 \\
{[10.7]}\end{array}$ & $\begin{array}{c}114 \\
{[9.1]}\end{array}$ & $\begin{array}{c}13 \\
{[4.6]}\end{array}$ & $\begin{array}{c}54 \\
{[9.9]}\end{array}$ & $\begin{array}{c}50 \\
{[11.4]}\end{array}$ & $\begin{array}{c}117 \\
{[9.25]}\end{array}$ \\
\hline $6 / 18-6 / 60$ & $\begin{array}{c}0 \\
{[0]}\end{array}$ & $\begin{array}{c}20 \\
{[3.6]}\end{array}$ & $\begin{array}{c}14 \\
{[3.4]}\end{array}$ & $\begin{array}{c}34 \\
{[2.6]}\end{array}$ & $\begin{array}{c}0 \\
{[0]}\end{array}$ & $\begin{array}{c}23 \\
{[4.5]}\end{array}$ & $\begin{array}{c}32 \\
{[6.9]}\end{array}$ & $\begin{array}{c}55 \\
{[4.4]}\end{array}$ \\
\hline Total & $\begin{array}{c}282 \\
{[100]}\end{array}$ & $\begin{array}{c}536 \\
{[100]}\end{array}$ & $\begin{array}{c}447 \\
{[100]}\end{array}$ & $\begin{array}{l}1265 \\
{[100]}\end{array}$ & $\begin{array}{c}282 \\
{[100]}\end{array}$ & $\begin{array}{c}536 \\
{[100]}\end{array}$ & $\begin{array}{c}447 \\
{[100]}\end{array}$ & $\begin{array}{l}1265 \\
{[100]}\end{array}$ \\
\hline $\begin{array}{c}\chi^{2} \text { Value } \\
(\mathrm{df}-4)\end{array}$ & \multicolumn{4}{|c|}{26.535} & \multicolumn{4}{|c|}{32.057} \\
\hline p Value & \multicolumn{4}{|c|}{$0.003^{*}$} & \multicolumn{4}{|c|}{$0.000^{*}$} \\
\hline \multicolumn{9}{|c|}{ Table II. Age Wise distribution of Visual Acuity } \\
\hline
\end{tabular}




\section{DISCUSSION}

The present study observed that mean age of the study population was $10.99 \pm 2.706$ years and VA $\leq 6 / 9$ was taken as defective vision. Out of total 172 children (13.6\%) were found to have defective vision in one or both eyes. Among boys $9.1 \%$ had defective vision and among girls $16.7 \%$ had defective vision. The difference observed between them was significant. The prevalence of defective vision was more in higher (early adolescent) age groups as compared to lower (preadolescent) age groups. Maximum 14.1\% students with defective vision belonged to 13 - 15 years' age group followed by $13.6 \%$ and $4.3 \%$ in $10-13$ years' and $6-10$ years' age groups respectively. The defective vision was significantly associated with increase in age group.

In this study, a total of 172 children (13.6\%) were found to have visual acuity $<6 / 6$ in one or both the eyes. This finding is similar to those of Gupta et al, ${ }^{7}$ where prevalence was found to be $13.2 \%$ in school children (4 - $12 \mathrm{yrs}$.) of Aligarh. Batra et $\mathrm{al}^{8}$ also observed the prevalence of VA $\leq 6 / 9$ in $12.7 \%$ school children (5 - 15 yrs.) from both rural and urban areas of Ludhiana city.

Bayoumy et $\mathrm{al}^{9}$ found $51.3 \%$ prevalence of $\mathrm{VA}<6 / 6$, Mondal et $\mathrm{al}^{6}$ found $31.1 \%$, Rustagi et $\mathrm{al}^{10}$ found $23.1 \%$ prevalence of VA $\leq 6 / 9$ in school children of rural area of Delhi. The higher prevalence was probably due to older age group covered in the study. Yared et al,11 Shaffi et al ${ }^{12}$ and Madhavi MR et al ${ }^{13}$ observed $8.1 \%, 3.11 \%$ and $6.3 \%$ prevalence respectively.

In the present study, $\mathrm{VA} \leq 6 / 12$ in better eye was found in 72 students (5.7\%). Ghosh $\mathrm{S}^{14}$ et al found $4.2 \%$ prevalence among urban school children of low-income families in Kolkata. Rustagi et $\mathrm{al}^{10}$ and Yared et al ${ }^{11}$ found $2.6 \%$ and $1.1 \%$ prevalence respectively, while Mondal et $\mathrm{al}^{6}$ and Bayoumy et $\mathrm{al}^{9}$ found greater prevalence in $13.7 \%$ and $9.7 \%$ respectively.

According to WHO criterion of vision impairment, i.e. VA $\leq 6 / 18$ in better eye was found in 32 students $(2.5 \%)$ in this study. This finding is comparable to study of Yared et al,11 who found $2.4 \%$ prevalence. Mondal et $\mathrm{al}^{6}$ found $3.7 \%$ and Byoumy et $\mathrm{al}^{9}$ found $11.3 \%$.

As per WHO severe vision impairment, i.e. VA $\leq 6 / 60$ in better eye was found in 2 students $(0.16 \%)$ in this study. Madhavi MR, ${ }^{13}$ Yared et al, ${ }^{11}$ Rustagi et al ${ }^{10}$ and Bayoumi et $\mathrm{al}^{9}$ found $0.37 \%, 0.4 \%, 0.6 \%$ and $1.1 \%$ prevalence respectively.

\section{CONCLUSION}

Screening of the refractive errors in school should be carried out periodically. In addition, school going children and their parents should be educated about signs and symptoms of refractive errors, ocular hygiene and the risk factors involved in the development of refractive errors and other ocular pathological problems. Vision screening of school children in developing countries could be useful in detecting curable causes of vision problems provided detected at the early stage, especially refractive errors by which long-term visual disability could be avoided.

\section{REFERENCES}

[1] WHO fact sheet. Available from http://www.who.int/mediacentre/factsheets/fs282.

[2] Vision screening in school children. Training module. Danish assistance to the national programme for control of blindness. New Delhi, India: 2004.

[3] Gilbert CE, Anderton L, Dandona L, et al. Prevalence of visual impairment in children: a review of available data. Ophthalmic Epidemiol 1999;6(1):73-82.

[4] Prema N. Prevalence of refractive error in school children. Indian Journal of Science and Technology 2011;4(9):1160-61.

[5] Visual acuity: what is $20 / 20$ vision? Available at: https://www.aoa.org/patients-and-public/eye-andvision-problems/glossary-of-eye-and-visionconditions/visual-acuity?sso=y.

[6] Mondal K, Manna N, Dasgupta U, et al. A study of visual acuity among the students in a rural girls high school of West Bengal. IOSR Journal of Dental and Medical Sciences 2013;10(2):12-6.

[7] Gupta M, Gupta Y. A survey on refractive error and strabismus among school children in a school at Aligarh. Ind J Public Health 2000;44(3):90-3.

[8] Batra N, Kaushal D, Gill AS. Refractive errors in school children-data from a school. Tropical Ophthalmology 2007;7(3):43-7.

[9] EL-Bayoumy BM, Saad A, Choudhary AH. Prevelance of refractive error and low vision among schoolchildren in Cairo. Eastern Mediterranean Health Journal 2007;13(3):575-9.

[10] Rustagi N, Uppal Y, Taneja DK. Screening for visual impairment: outcome among schoolchildren in a rural area of Delhi. Indian J Ophthalmol 2012;60(3):203-6.

[11] Yared AW, Belaynew WT, Destaye S, et al. Prevalence of refractive errors among school children in Gondar town, northwest Ethiopia. Middle East Afr J Ophthalmol 2012;19(4):372-6.

[12] Shaffi M, Bejiga A. Common eye diseases in children of rural community of Goro district, central Ethiopia. Ethiop J Health Dev 2005;19(2):148-52.

[13] Madhavi MR, Kesuraju VK, Nagrale P, et al. Ocular morbidity among school aged children in Indian scenario. Int J Res Med Sci 2015;3(6):1431-4.

[14] Ghosh S, Mukhopadhyay U, Maji D, et al. Visual impairment in urban school children of low-income families in Kolkata, India. Indian J Public Health 2012;56(2):163-7. 